Vol. 02, No. 1, January 2018, 97-114

Avalaible at: https://ojs.unud.ac.id/index.php/UJLC/issue/view/2675

E-ISSN 2549-0680

\title{
Does Customary Law Discriminate Balinese Women's Inheritance Rights?
}

\author{
Hanna Christine Ndun*
}

Faculty of Law Udayana University

\author{
Sarah Suttor**
}

Charles Darwin University School of Law

\section{Gusti Agung Ayu Dike Widhiyaastuti***}

Faculty of Law Udayana University

\begin{abstract}
There is a stereotype with regard to the rights of the Balinese women on inheriting under the Balinese traditional customary law. It is generally assumed that the law discriminates Balinese women as well as against the human rights principle of equality. This article analyzes the contemporary problems of such issue and would demonstrate the actual principles, rules and practices, including the essential concept of the rights under the Balinese traditional customary law of inheritance. This issue has been explored under a normative legal approach where the resources are primarily taken from the relevant national legal instruments and court decisions, instead of textbooks and journals. An interview has also been commenced for clarifying some aspects of the issue. This article concludes that there has been a generally misleading on viewing the Balinese customary law as discriminating women on an inheritance issue, as in fact, the law also provides rules for supporting women's rights for inheriting. The law in a certain way has properly preserved the right of women for inheriting in which women under the law have also enjoyed rights for inheriting, especially the daughter and widow. In contrast, the Balinese men that are generally perceived as the ultimate gender enjoying privileges rights to inherit, in the practice of inheritance in the traditional community are also subject to some discrimination. The law has provided a set of rule of inheritance both for men and women where they are subject to certain equal rule and condition. The law also clarifies that both genders are enjoying equal rights on inheritance in a certain portion and situation binding under the principle of balancing between rights and obligation for each side.
\end{abstract}

Keywords: Inheritance rights, Women rights, Balinese women, Customary law

How to cite (chicago-16th): Christine Ndun, Hanna. "Does Customary Law Discriminate Balinese Women's Inheritance Rights?” Udayana Journal of Law and Culture 2, no. 1 (2018): 97-114. https://doi. org/10.24843/UJLC.2017.v02.i01.p05.

DOI: https://doi.org/10.24843/UJLC.2018.v02.i01.p05

* Email: hcndun@gmail.com

** Email: sls_suttor@hotmail.com

*** Email/Corresponding Author: ayu_dike@unud.ac.id and dikewidhiyaastuti@gmail.com 


\section{Introduction}

\subsection{Background}

As Bali Province is an integral part of the Republic of Indonesia, foreigners may assume that any private issue simply falls under the Indonesian private law which strongly influenced by Western values, especially Dutch. This assumption is misleading. Despite many efforts have been done by the Government of the Republic of Indonesia for unifying and harmonizing the Indonesian private law, some matters are still left to customary law or known as Adat law. Such law refers to a law that is created by, accepted by, and implemented by the traditional community within their territory and among their community member. The 1945 Constitution of the Republic of Indonesia and some other Acts ${ }^{1}$ have fully recognized the existence of this customary law. Hence, the law plays a significant role in governing the communities.

There are some nearly 1.500 traditional communities around Bali with their autonomous community system. ${ }^{2}$ The Constitution awards them certain constitutional rights including rights to own territory, autonomous governmental system, people, and legal system. They are deserved to appoint their leader and management system, create their own law, to perform and enforce it within their territory.

One issue that reflects the power of the Balinese customary law is the matter of inheritance. For centuries, only men are preserved right for inheriting due to the patriarchal system. Therefore, in a very surface of analysis, it easily concludes that only men are deserved for inheriting and women are obviously discriminated from the rights of the beneficiary.

The enlightenment of human rights, as well as the teaching of gender and feminism, have instantly opened some Balinese mind and make them questioning on the strict understanding of granting only men to inherit. It has driven some social and cultural debates that turned people into a dynamic situation. It is worth to acknowledge that academician, Majelis Desa Pakraman (Customary Village Assembly in Bali) ${ }^{3}$ and also court play a significant role in shifting these progressive concerns. They have made an effort to enlighten and providing a greater understanding with regard to the effect of customary inheritance law in the Balinese traditional communities.

1 Act of the Republic Indonesia No. 5 Year 1960 concerning Basic Regulation on Agraria, Art.5 and Act of the Republic of Indonesia No. 39 Year 1999 concerning Human Rights, Art.6.

2 “Tahun 2017 Majelis Utama Desa Pakraman Bali Kukuhkan 5 DP Baru, Salah Satunya di Tabanan," December 8, 2017, https://www.beritabali.com/read/2017/12/08/201712080017/Tahun-2017-MajelisUtama-Desa-Pakraman-Bali-Kukuhkan-5-DP-Baru-Salah-Satunya-di-Tabanan.html

3 Majelis Desa Pakraman is an assembly that coordinates the customary villages in Bali. It has hierarchy structure as follows: The top position is called as Majelis Utama Desa Pakraman that chairing at provincial level; the middle level at regency/municipality is called as Majelis Madya Desa Pakraman; the lower level is what so-called as Majelis Alit Desa Pakraman that coordinates customary villages in the territory of district / sub-regency. See further explanation in Section 2.5. 


\subsection{Method and Structure}

This article analyses the women inheritance rights in the Balinese traditional community. In general, it tries to explain the women inheritance rights in Balinese customary law and its impact. This writing is specifically aimed at gaining and exploring the issue of the Balinese women discrimination to inherit under the Balinese customary law. It is also expected to bring an impact to the community perception with regard to rights of the Balinese women for inheriting including redefining its concept.

\subsection{Methodology and the Structure of Article}

The writing has been based on a normative legal method and primarily based on a library research. Norms on inheritance are taken from relevant national legal instruments besides from selected decisions awarded by Court. It is also supported by resources that provided in textbooks and journals as well as social sciences literature. Clarification to sources and resources are obtained from interview to relevant experts.

The structure of this article covers the following elements: Section 2.1 presents a literature review to see the number of people who put attention on inheritance law in Indonesia. Next, Section 2.2 provides an analysis on legal pluralism in inheritance laws of Indonesia which aimed at introducing the inheritance law of Indonesia. Subsequently, the role of the Indonesian Supreme Court on the development of the Indonesian customary law with regard to the issue will be discussed in Section 2.3. Section 2.4 will describe the inheritance rights in Balinese traditional community while Section 2.5 will analyze the system of the Balinese customary law of inheritance and its impact on the rights of the Balinese women to inherit. The last part of this writing is the conclusion as provided in Section 3.

\section{Result and Analysis}

\subsection{Literature Review}

The issue of limited rights of women to inherit is not limited only to the Balinese women, but also some others on this planet. ${ }^{4}$ Such limitation attracts a lot of attention of the academician for finding factors causing the problem existed. Yeni Salma Barlinti wrote an article compares three systems of inheritance law, analyzes the issue of personality principle and assesses the way courts implement the system in the legal

4 See for example the situation of women in India in Prerna S. Ramteke, "Knitting the Future Story of Indian Women: Preventing Violence, Fostering Development, and Accelerating Empowerment", Udayana Journal of Law and Culture 1, no.2 (2017):113. See also the obstacles for women in Rwanda to inherit their parents' lands in Aparna Polavarapu, "Procuring Meaningful Land Rights for the Women of Rwanda", Yale Human Rights and Development Journal 14, no.1 (2014):108-110. 
proceedings. ${ }^{5}$ The research reveals that the employing of the three systems of inheritance law in Indonesia (Adat, Islam, and Western) are remain existed as quite many inheritance disputes are submitted before the courts. ${ }^{6}$ Dyatmikawati published an academic paper that analyses the development of customary law in Bali with regards to the women rights to inherit particularly in the context of constitutional guarantees that Indonesian citizen is equally treated before the law and community. ${ }^{7}$ Her juridical research assesses that Balinese women positioned by both Indonesian national law and Balinese customary law especially for the issue of the right to inherit their parent's property. $^{8}$

Helen Creese wrote an article that reveals how Balinese Law Codes has considered and governed the rights to property and inheritance of the female both within marriage and following divorce or death. ${ }^{9}$ Meanwhile, Ni Ketut Sri Rasmini describes that the kinship systems in indigenous people in Bali are patrilineal and there is three kind of inheritance systems such as individual, collective and mayorat. ${ }^{10}$

Another writer, I Nengah Ardika identifies three approaches that may be used to analyze the issue of granting rights of inheriting of the Balinese women. ${ }^{11}$ Under the first approach, the philosophical approach, such granting of rights reflects a substantive justice, ${ }^{12}$ while under the second approach, the legal approach, it implies a concern on gender equality. ${ }^{13}$ Lastly, the sociology approach views that the granting of inheritance rights for the Balinese women is in line with the times as the current civilization widely recognized the equality between men and women. ${ }^{14}$

A Dutch scholar Ingrid Westendorp assesses how Balinese women are discriminated against their rights in the matters of inheritance based on religious and traditional laws. ${ }^{15}$ Despite the Hindu holy book Manawa Dharmasastra underlines the

5 Yeni Salma Barlinti, “Inheritance Legal System In Indonesia: A Legal Justice For People”, Indonesia Law Review 1, no.1 (2013): 23, http://dx.doi.org/10.15742/ilrev.v3n1.28

6 Ibid, 39-40.

7 Putu Dyatmikawati, "Inheritance Rights of Women Based on Customary Law in Bali", International Journal of Business, Economics and Law 11, no. 4 (2016): 13.

8 Ibid.

9 Helen Creese, "The Legal Status of Widows and Divorcees (Janda) In Colonial Bali", Indonesia and the Malay World 44, no. 128 (2016), https://doi.org/10.1080/13639811.2015.1100862

10 Ni Ketut Sri Ratmini, "Hak Warisan dan Hubungannya dengan Daha Tua Menurut Hukum Adat Bali, Udayana Master Law of Journal 4, no. 2 (2015), https://doi.org/ 10.24843/JMHU.2015.v04. i02.p19

11 I Nengah Ardika,"Pemberian Hak Waris Bagi Anak Perempuan di Bali Dalam Perspektif Keadilan", Jurnal Magister Hukum Udayana 5, no. 4 (2016) : 639 - 649, https:/ / doi.org/ 10.24843/JMHU.2016. v05.i04.p01

12 Ibid, 643-644, 647.

13 Ibid, 639, 647.

14 Ibid, 643-645, 647.

15 Ingrid Westendorp, "Personal Status Law and Women's Right to Equality in Law and in Practice: The Case of Land Rights of Balinese Hindu Women", Journal of Human Rights Practice 7, no.3 (2015): 433, https://doi.org/10.1093/jhuman/huv013 
equality rights of male and female persons to inherit, they are supposed to play different roles in society and therefore are entitled to different privileges commensurate with these roles. ${ }^{16}$ She then argues that the customary rules applied for the aspects of family, marriage, and inheritance are not based on equality, but equity, entails with a situation that a person will have rights and duties that befit his or her gender and status in society. ${ }^{17}$

Edo Hendrako explained that under the Balinese customary law of inheritance, the rights of inheriting may be distributed not just after the testator die, but also when the testator still alive. ${ }^{18} \mathrm{He}$ also describes that the patrilineal kin system positioned man higher rather than women. It leads to veiled gender discrimination in Balinese customary law. ${ }^{19}$ In his view, the phenomenon makes man usually positioned women in the second line and receive less attention. In some areas in Bali, parents intentionally did not give a proper education to their daughters because they thought their daughters will not give them anything in return and later on they will move to their husband family. ${ }^{20}$

Under the result of research carried out by Ni Luh Gede Isa Praresti Dangin, Koesno Adi, and Iwan Permadi, the inheritance rights closely related to the responsibility of taking care of the parent. After married the daughter generally leaves her family and starts a new life in the husband family. Under the kinship systems the responsibility to accompany the parents, and to some extent, substitute parent customary obligations will be carried out by their son. This is the reason why inheritance rights are given to the son, not to the daughter. It can be acknowledged that social reality shows that daughters inherited from her parents in terms of a gift of marriage that is called "jiwa dana", "tetatadan", or "bebaktan". The parents can even conduct a ceremony to change the status of "daughters" to become "sons" in what is called "sentana rajeg", so that the daughter becomes the rightful heir to the inheritance of her parents. ${ }^{21}$

A research in the field of Hinduism carried out by Ni Kadek Setyawati discovers that in the period before 1900 the Bali-Hindu society has applied the absolute purusa system which that determines men as heirs for their parents' inheritance. By 1900 onward, some jurisprudences and decisions adopted by Customary Village Assembly reflect gender equality that enables women to inherit in the Balinese family. This research also found that the strong patrilineal culture prevailing in indigenous

16 Ibid, 433-434.

17 Ibid, 434.

18 Edo Hendrako, "Hak Waris Anak Perempuan terhadap Harta Peninggalan (Studi Kasus Putusan MA RI No. 4766/Pdt/1998)”, Lex Privatum 3, no. 1 (2015): 84.

19 Ibid, 86.

20 Ibid.

21 See further in Ni Luh Gede Isa Praresti Dangin, Koesno Adi, Iwan Permadi, "Kedudukan Hak Mewaris Wanita Hindu dalam Sistem Hukum Adat Waris di Bali", Jurnal Hukum, Magister Ilmu Hukum dan Kenotariatan Universitas Brawijaya (2015). 
Balinese society has made the position of women not fully acknowledged, even in the case of female decision making in the family they are not taken into account. Arguing that responsibilities of Bali-Hindu women in a family, marriage and society are not much different to the responsibilities of men, consideration to give women an opportunity to have equal legal status with men, especially in the issue of inheritance under the customary law of Bali, need to be reasonably taken into account. ${ }^{22}$

\subsection{Legal Pluralism and Inheritance Law In Indonesia}

Inheritance issue is always interesting to be discussed as many of problems often arise from it. Inheritance may cause friction or even dispute among family members as they receive properties from descendant either by will or the state law of intestate succession. The issues closely related to the right to inherit, properly when the properties transferred from the died person to the heirs.

There are several inheritance laws existed in Indonesia such as the Indonesian Private Law, the Customary Law, and the Religion Law. The Indonesian Civil Code is a codification on the Private Law which has been adopted from Dutch law legal system during the colonialism era and remain valid in the recent day. There is no doubt that Indonesian laws of inheritance strongly bound by the old school of the Western legal thinking. The second is the inheritance law based on the Indonesia traditional customary law which is created, accepted and applied by and within Indonesia traditional communities. The third law is the Religion laws which are sourced in the holy book of each religion. There are arround six religions existed in Indonesia namely Islam, Christian (Protestant), Roman Catholic, Hindu, Buddha, and Confucianism. Such Religion laws applied to their fellows. For instance, Islamic inheritance law mostly applies to Moslem people while Christians and Buddhist mostly rely on Indonesian private laws. The implementation of Indonesian private laws in the inheritance cases do not as much as the implementation of the inheritance of customary laws and the religious laws.

Customary inheritance laws are generally applied in the genealogical and territorial tribes such as Bali, Sasak, Batak and other customary communities in Indonesia. This law of inheritance is part of the Customary law, that is a set of rules contains the living values, appreciated, upheld and implemented by the traditional community. ${ }^{23}$ Due to Imam Sudiyat, customary inheritance law contains rules and policy which are related to the forwarding/passing and switching/shifting the material and nonmaterial property from generation to generation. ${ }^{24}$ Meanwhile, in Ter Haar comprehension, customary inheritance law is the rule of law covers the way of

22 Ni Kadek Setyawati, "Kedudukan Perempuan Hindu Menurut Hukum Waris Adat Bali dalam Perspektif Kesetaraan Gender”, Jurnal Penelitian Agama Hindu 1, no. 2 (2017): 618.

23 I Gede A.B. Wiranata, Hukum Adat Indonesia Perkembangannya dari Masa ke Masa, (Bandung: PT. Citra Aditya Bakti, 2005), 21.

24 Ibid, 256. 
forwarding and switching the tangible and intangible property from the predecessor to the succeeding generation. ${ }^{25}$ The main principle of inheritance is kinship principles which influence the laws.

Referring to Soerjono Soekanto, customary inheritance law in Indonesia is influenced by the kinship principle. It could be the pure patriarchal principle, alternated with the patriarchal principle, matriarchal or bilateral even it is difficult to say where is exactly it applied in Indonesia community, and also work the double unilateral principle. ${ }^{26} \mathrm{He}$ perceives that this kinship principle usually influences the inheritor's determination or which portion of the property shall be inherited, the material or immaterial.

The religion law, such as Moslem, is mostly embraced by the Indonesian. The main resource of inheritance law in Moslem religion is the holy book of Quran which is called Fiqh or the Moslem inheritance law. It aims to avoid controversy with regard to inheritance property which left by the ancestor and avoid one heir feels more rightful than the others. Then, the distribution of the inherited property more just among the heritance and less conflict may be created. In accordance to such aimed, Moslem obey a doctrine of inheritance provided by the Quran shown in Quran Letter An-Nisaa section 11 to 12 and Letter An-Nisaa section $176 .{ }^{27}$

The Hindu law in Indonesia does not stand alone and governs the Hindu people straightly. It is absorbed into the Indonesian customary laws, in particular in the practice of Hindu society in Bali where Hindu law embraced by adat law.

Hence, there is a legal pluralism in the Indonesian inheritance laws as reflected in various kinds of inheritance law such as the Indonesian private law, the traditional customary law and the religious law. One of the interesting matters to explore is the customary inheritance laws. There are some problems existed in the traditional community related to the heirs, heir's obligations, and the property. The problem mostly complicated under the nature of the customary inheritance laws such as strict and perhaps harmful against the heirs, particularly women.

\subsection{The Role of the Indonesian Supreme Court}

Elfrida Gultom discovered that some decisions awarded by the Indonesian courts in the case of inheritance reflected that position of men and women tends to become just and equal as mostly shown in the parental system. Some courts positioned women as equal as men, sometimes treated as a neutral party in conformity with the values of modernization leads to heterogeneity and equality as well as in the sense of

\footnotetext{
25 Ibid.

26 Soerjono Soekanto, Hukum Adat Indonesia, (Jakarta: PT. RajaGrafindo Persada, 2011), 259-260.

27 See "Hukum Waris Islam dan Pembagiannya,"https://dalamislam.com/hukum-islam/hukumwaris-islam
} 
inheritance law which brings a great impact to the practice of inheriting in the Batak, Karo and Bali traditional community. ${ }^{28}$ Some Indonesia Supreme Court decisions awarded an equal position, treatment, and opportunities for women to inherit especially to children and widow inherit rights. In the ruling of Supreme Court Decision Number 179/Sip/1961, dated 23 October 1961, it says:

"....based on humanity and common justice, also the equality rights between men and women, in some decision made, Supreme Court takes an attitude and assume as the living laws in Indonesia, that daughters and sons of the dying person equally have the rights as an heir to inheritance property in the sense that both sons and daughters have the same portion. ....under such vision, in Karo land, daughter also become a descendant which have a inherit rights to her parent's inheritance property."

In that Karo Land case, Supreme Court rules that daughter shall be given inheritance rights, as well as man, although the distribution may not similar to the man.

A judgment awarded by Indonesia Supreme Court in 1968 strengthened its previous decision in 1961. In the Supreme Court decision No. 100K/Sip/ 1967 dated 14 June 1968, the Court stated that “....regards to community development at this time which is toward to equation and equality between men and women, and the widow as a descendant act constitute jurisprudence by the Supreme Court...". This decision in lines with the principle of binding power of the Supreme Court jurisprudence, which particularly binding upon the disputing parties and not to the other. This decision entails that Indonesia woman who is bound by their customary law can propose their position as a descendant and obtain inheritance rights.

It has been for two decades the Supreme Court has played a role in the development of Indonesian customary law in particular with regard to the development of rights of woman in the Balinese traditional community to inherit from their parents. In the Supreme Court decision Number. 4766/Pdt/1998, dated 11 June 1999, the Court has decided that the Balinese daughters may also be a descendant and hold inheritance rights to inherit the property of their father. The Court has started aware to the position of the woman within the life of the traditional community which shall be improved in a proper way. So, they may own rights for inheriting including in the patriarchal system where women mostly ignored by the system. Under its decision, the Court has started granting rights for inheriting to the women even though they live within a society which prevail patriarchal system. The women shall be positioned as equal as men do in the case of inheriting. They should be given an opportunities to inherit from their family as the facts that the Hindu' law does not put or treat women in discrimination, but equal due to their natural rights and obligation even though they are totally different by gender, position and function in

28 Elfrida R Gultom, "Development of Women Position in the Patrilineal Inheritance of Indonesian Society," Jurnal Dinamika Hukum 17, no. 2 (2017): 194-202, http://dx.doi.org/ 10.20884/ 1.jdh.2017.17.2.886 
the life of the society. In addition, the development of human rights has also strongly supported the idea of equal rights between man and women in the sense of rights for inheriting.

In NY. Jance Faransina Mooy-Ndun v.Junus Ndoy et.al Case, Indonesian Supreme Court in 2012 brought up the idea of human rights in supporting their decision. The Court has cited Article 17 of the Act Number 39 of 1999 concerning Human Rights and the 1961 Jurisprudence showing that women's inheritance is equated to men. ${ }^{29}$ The consideration of the Decision also mentioned that customary law has no longer consistent with the progressive development of law recently. The customary law does not recognize women's rights equivalent to the position of men, can no longer be maintained. ${ }^{30}$

\subsection{Inheritance Rights In Balinese Customary Law}

Balinese Customary Law is a part of the traditional or indigenous law which is existed in the Balinese traditional community. Balinese customary laws absorb some contents of the Hindu law such as Manawa Dharma Sastra and Catur Agama (the four basic rules) into its rules Based on this facts, the Balinese Customary Law is classified as a unique law as it merges Hindu laws into its content. It has a consequence upon its function or binding power such as it only prevail to the Balinese people who are Hindu. There are some three million people living in Bali are Hindu and the rest are consist of non-Hindu like Moslem, Buddhism, and Christian. They all live within the traditonal community as community guests (krama tamu) and are generally not bound by the balinese customary law.

Balinese Customary Law regulates the relationship amongst human being, between human and environment, and between human and the Gods within the community. Such regulations are provided in the law, called awig-awig, which maintain order within the community and preserve safety and security for the social life of the community. Each traditional community has their own adat law and strongly influenced by their particular condition, space (desa) time (kala) and situation (patra). However, there are a kind of common elements contained in the law, it is the concepts of habitual elements called Catur Dresta or the four basic elements of law consist of the old tradition (Pura dresta), religion rules (sastra dresta), general public rules and opinion (loka dresta), and local public opinion (desa dresta). It makes the village rules (awig-awig) become flexible, dynamic and responsive to the world development. Almost none of the Balinese people behave contrary against the law, they commonly accept and obey the law with full respect and obedience.

29 Decision, Indonesian Supreme Court, No. 1048 K/Pdt/2012, 26 september 2012, 26-27, https:// putusan.mahkamahagung.go.id/putusan/downloadpdf/38ce125c6a11b95444de7a70b8e73fae/pdf

30 Ibid, 27. 
Balinese inheritance law is based on Hindu and the Balinese kinship system. So, it is a kind of mix between religion and the people tradition. Balinese kinship system followed the patriarchal system which is a lineage of men. In the patriarchal system, men own full rights for inheriting the property of the father in accordance with the vertical line (line up and down) and a horizontal line or the sideline. As an example, supposedly a Balinese man, name Wayan, a sole son of his father, Pan Wareg, ${ }^{31}$ and he has some sisters. In this illustration, Wayan will own the full rights to inherit his father's property. Supposedly Pan Dadung, the brother of Pan Wareg, has no son or daughter, then Wayan will take a position as the Pan Dadung heir and he will certainly inherit the Pan Dadung's property. So in the patriarchal system, there is no chance for women, such daughter or sisters, niece and widow to own rights for inheriting.

Under the Balinese inheritance law, there are four elements of inheriting play an important role, such as: ${ }^{32}$

1. The ancestor, the one who has the rights to inheritance property (powers);

2. The inheritance (warisan);

3. The descendant (waris); and

4. The heirs (ahli waris).

These four elements contain a different concept of inheritance and have caused the customary inheritance law differ to the Indonesian private laws, as the law only measuring some elements of inheriting such as ancestor, inheritance, and the heirs. The Indonesian law has no conceptions of descendant prevailed in the Balinese customary law. Inheritance (waris) means the descendant which arises to the next generations of the ancestor (pewaris), it could be the ancestor's children, both men and women, and also the ancestor's grandchild, either men or women. The descendant does not only own the inheritance rights as an heir (ahli waris), but inheritance rights by the law or by the will.

In the patriarchal system, a son who is adopted by ancestor also has a rights to inherit similar to the biological son of the heir. Balinese inheritance law shows that the law has influenced much by the patriarchal principle causing some conditions applied to both biological son and adopted son, such as:

1. They do not perform a nyeburin marriage (a man who shifting his status from men to women and starts the new obligation as in the wife house)

31 Pan is an abbreviation Bapan, means the father of [name of the son). In this illustration, Wareg is the given name.

32 Interview with I Wayan Windia, at Bali Santhi Secretariat, Denpasar, 4 December 2015. 
2. Already run and bear their dharmaning (the concept of obligation in Hindu) as a child.

If they disobey those conditions, they will not be regarded as a descendant and have no rights at all, similar to the Balinese women have.

In Balinese inheritance laws, women, such as daughter and widow, commonly have no rights to be an heir and inherit an inheritance property. They have a particular right to the property as long as they do not release their rights. There are rules for Balinese women provided by the law who will lose their particular right to inherit the property, such as: ${ }^{33}$

a. For daughters:

1. She is married and moved to husband family;

2. She has not recognized anymore as a child by her parents.

b. For widows:

1. She is betraying (bergendak);

2. She is married again with another person.

The most important thing in inheritance under the customary law, especially in Balinese traditional community law, is the descendant of the family. There is a peculiar concept of a descendant in Balinese thinking based on the Hindu conceptions of a descendant. It is regulated in Manawa Dharma Sastra Section IX:106 which stipulated that the descendant as they were birth, they shall be released from the debts and sins to the ancestor (died parents, grandfather) and for that reason, men deserve to get the inheritance rights. Based on the conceptions, the inheritance right in Balinese inheritance laws belongs to the men, not the women. Due to the Balinese inheritance laws, married women do not have any rights to the family inheritance, the different condition will apply to the unmarried woman. She will retain full rights to inherit. However, if the woman takes a role as a man and bring a man to her lineage as a woman (sentana rajeg), this means she will fulfil the man obligations and in this instance, a woman assumes full inheritance rights. This kind of marriage is called "nyeburin". This research discovers that the Balinese inheritance laws recognize both genders have an equal opportunity to own rights to inherit. So, the Balinese inheritance law actually does not discriminate woman as the law has measured them in a certain way due to their rights and obligation in their origin family.

33 Soerjono Soekanto, Op.Cit, 264. 
Besides the rights to inherit, Balinese customary inheritance law also imposes an obligation to the men, in line with their position as an heir, to preserve and maintain the inheritance property. This obligation, in fact, is a hard obligation.

In the Balinese inheritance laws, inheritance property comprising: ${ }^{34}$

1. the inheritance itself, such as:

a. undivided inheritance means the inheritance property which has magical and religious values such as Hindu family temple (merajan, sanggah), worship tools (Siwa Karana), family's iconic and magical weapons (keris), etc;

b. divided inheritance such as rice field, farmland, land, and etc.

2. the congenital property, that is a property belongs to the bride or the grooms which are brought to marriage such as known as Jiwa dana, tatadan and akskaya;

3. marriage property, that is a property which has been obtained during the times of marriages (guna kaya); and

4. the community rights such as worship in territory-based community temples (kahyangan tiga), the use of customary cemetery, and performing Hindu ceremonies such as Pitra Yadnya, a ceremony performed for purifying the soul of the passed away family members, which mostly big and absorbing a huge amount of money.

For some situation, the inheritance property is also included all kind of debts which is left by the ancestor. The heir is under obligation to settle the ancestor debts. It describes by the law that under the Balinese inheritance laws, the inheritance property shall cover the tangible and intangible property. One of the harder things under the Balinese inheritance laws is that the intangible property, especially the community rights and undivided property, is much more related to norms applied to the community. Therefore, the Balinese inheritance law does not solely a material property but also an immaterial property which corresponds to the three concept of responsibility includes responsibility to Gods expressed under the concept of parahyangan, responsibility to the community expressed in the concept of pawongan, and responsibility to the territory or environment of the community expressed in the concept of palemahan. These three concepts also become a part of the obligation to fulfill by those who awarded the rights to inherit.

The above structure and elements of the Balinese Customary Law on inheritance show that the concept of inheritance under the law very much relies on the basic concept of inclusive justice where justice is measured under the balance between rights and obligation of a particular subject of law. Instead of enjoyment of rights,

34 Ibid, 227-278. 
the man who inherits is also bear a certain obligation to be performed as the balance of the rights they got. However, there is a certain note under the Balinese Customary Law that woman as the family member is certainly measured under the Balinese inheritance law. The law has set up a package of the requirement for those who deserved to inherit. Any women who follow such requirements would be guaranteed by the law that they will hold their rights and those who fail to fulfill the requirements will lose their right to inherit.

\subsection{The Impact of The Balinese Inheritance Law on the Inheritance Rights of Women}

In the patriarchal systems, the right to inherit belongs to men as the rightful descendant of his father. The patriarchal system prevented women to own rights on inheriting. The Balinese customary laws prevail in similar rules of inheritance. It embraces the patriarchal principals in its kinship systems. Under the Balinese customary laws, women seem to have no rights to be descendant of his father. A foreigner may assume that the Balinese inheritance law discriminates against women, both daughters and widows. Interestingly, an expert in Balinese Customary Law, I Wayan Windia, has a non-mainstream view by arguing that the Balinese inheritance law does not only discriminate women, but also the men. ${ }^{35} \mathrm{He}$ said women who become a widow and back to their home as a daughter when she got divorced or suffered a dead divorced will enjoy a right to inherit the property of her origin family. This is one of the benefits for the women under the Balinese inheritance law. Although they have no rights to inherit as what Balinese men have, they actually own another kind of rights differ to the Balinese men. ${ }^{36}$ If they are married in a normal marriage, Balinese men never lose their inheritance rights and they are under obligation to take all obligations which left behind the ancestors which are not limited to the tangible property, but also the intangible property including debts. In another case, when a Balinese man become a widower in case of sentana rajeg (nyeburin marriage), he totally loses his inheritance right in his original house/family and has no inheritance rights in the women house/family. ${ }^{37}$

I Wayan Windia also revealed that there is a fallacious thought that Balinese women are fully discriminated from their inheritance rights as vice versa, they are also protected by the Balinese inheritance law itself. There is indeed a true impact of Balinese inheritance rights to the Balinese women, but the philosophy behind the rules seems improperly delivered by the previous generations. ${ }^{38}$

The progressive development of the Balinese traditional community law, following the establishment of the Bali Customary Village Assembly (Majelis Desa Pakraman)

\footnotetext{
35 Interview with I Wayan Windia, Op.Cit.

36 Ibid.

37 Ibid.

38 Ibid.
} 
and the issuance their decision, The Decision of the Village Assembly Number 01/ KEP/PSM-3/MDP Bali/X/2010, dated 15 October 2010 which determines the Balinese woman shall receive a half of the man (purusa) inheritance rights after diminished $1 / 3$ for inheritance and conservation interest. ${ }^{39}$ A condition of religion status is applied as a Balinese woman has no rights to inherit in case she converted to another religion. If her parents sincere, stay open mind and give a jiwa dana or voluntary provision. The Customary Village Assembly is an institution established under the Provincial Regulation of Bali Number 3 of 2001 concerning Desa Pakraman.

Unfortunately, this decision has less socialized to the customary community. The customary community seems not so aware of it, which means the Balinese customary law especially inheritance law still sets to the patriarchal system and gives limited rights to the Balinese women to inherit. I Komang Kawi Arta, under his discovery, found that most Bendesa Adat, the Chiefs of the Customary Community in the Bali Aga, the old village of customary community in Buleleng regency, do not accept yet the decision of that Customary Village Assembly caused by the customary community still maintain dresta (custom rules) in a strict way and because awigawig (traditional rules) and also their indigenous habits about the inheritance rights only belong to man in Bali Aga customary community; The Decision has also not been realized or implemented because of the cristallized paternalistic culture. Some adagium such as "gugon tuwon" and "anak mule keto dini", means that all things have been continuously believed and practiced as a tradition way in Bali Aga village of Buleleng Regency. In addition, ${ }^{40}$ such Decision has no implication to the legal standing of women in the Bali Aga Village because of none of those women claiming or complaining on their inheritance rights in their own family.

There is sought of a breakthrough in the marriage concept introduced by I Wayan Windia called pade gelahang where the wind of change are flowing out to a couple that has no son as the descendant they will secure their property through the marriage system. In this systems, both brides will have the same rights in inheritance laws and will take responsibilities in both families as a descendant. Both families may jointly conclude an agreement to determine, for example, one of their children will only take one obligation in the future, which can be in his/her mother home or father home. ${ }^{41}$

\section{Conclusion and Recommendation}

\subsection{Conclusion}

It can be drawn up that rules of Indonesian private laws are different from the rules of customary laws and religious laws. These three laws have their own characteristic on

39 See Putu Dhyatmikawati, Op.Cit, 16.

40 I Komang Kawi Arta, Ketut Sudiatmaka, Ratna Artha Windari, Realisasi Keputusan Pesamuhan Agung III MUDP Bali terhadap Pewarisan Anak Perempuan Bali Aga di Kabupaten Buleleng, e-Journal Komunitas Yustitia Universitas Pendidikan Ganesha Jurusan Ilmu Hukum 1, no. 1 (2018).

41 Interview with I Wayan Windia, Op. Cit. 
governing inheritance rights. In Balinese customary inheritance law, some concepts are very distinctive. Vice versa, Balinese women rights to inherit has properly protected under the Balinese customary law as shown in the concept of luxury exclusive rights belong to Balinese women which provides advantages to women (daughter and widow) to inherit. In contrary, men may absolutely lose their rights of inheritance in some conditions such as do a nyeburin marriage and if the men become a widower of nyeburin marriage. Men, in this case, do not have such rights as the women do. Based on construction, Balinese customary law protects properly both man and women rights' to inherit, in the same way, they are also subjected to discrimination on a certain occasion. Such structure makes clear that both genders have their own means of enjoying inheritance rights that applied in different situations.

\subsection{Recommendation}

In order to strive the progress, local government should take a position to disseminate the decision by Customary Village Assembly that clarifies the right of $\mathrm{Ba}$ linese women to inherit. As this assembly decision in line with Indonesian Human Rights Act, local government should create a programmatic action to socialize better understanding of the inheritance rights according to Balinese Customary Law. 


\section{BIBLIOGRAPHY}

\section{Book}

Wiranata, I Gede A.B. Hukum Adat Indonesia Perkembangannya dari Masa ke Masa, Bandung: PT. Citra Aditya Bakti, 2005.

Soekanto, Soerjono. Hukum Adat Indonesia, Jakarta: PT. Raja Grafindo Persada, 2011.

Windia, Wayan P. Hukum Adat Bali Dalam Tanya Jawab. Bali: Udayana University Press, 2013.

\section{Journal Article}

Ardika, I Nengah. "Pemberian Hak Waris bagi Anak Perempuan di Bali dalam Perspektif Keadilan.” Jurnal Magister Hukum Udayana 5, no. 4 (2016): 639 - 649. doi: https:/ / doi.org/10.24843/JMHU.2016.v05.i04.p01.

Arta, I Komang Kawi, Ketut Sudiatmaka, Ratna Artha Windari. "Realisasi Keputusan Pesamuhan Agung III MUDP Bali terhadap Pewarisan Anak Perempuan Bali Aga di Kabupaten Buleleng." E-Journal Komunitas Yustitia Universitas Pendidikan Ganesha Jurusan Ilmu Hukum 1, no. 1 (2018).

Barlinti, Yeni Salma, "Inheritance Legal System In Indonesia: A Legal Justice For People”, Indonesia Law Review 1, no.1 (2013): 23-41, http:/ / dx.doi.org/ 10.15742/ilrev. v3n 1.28

Creese, Helen, abstract "The Legal Status of Widows And Divorcees (Janda) in Colonial Bali", Indonesia and the Malay World 44, no. 128 (2016): 84-103. https://doi.org / 10.1080/13639811.2015.1100862

Dangin, Ni Luh Gede Isa Praresti, Koesno Adi , Iwan Permadi, Kedudukan Hak Mewaris Wanita Hindu dalam Sistem Hukum Adat Waris di Bali, Jurnal Hukum, Magister Ilmu Hukum dan Kenotariatan Universitas Brawijaya (2015)

Dyatmikawati, Putu. "Inheritance Rights of Women Based on Customary Law In Bali", International Journal of Business, Economics and Law 11, no. 4 (2016): 13-16. http:/ /ijbel.com/wp-content/uploads/2017/01/LAW-5.pdf 
Gultom, Elfrida R. "Development of Women Position in the Patrilineal Inheritance of Indonesian Society." Jurnal Dinamika Hukum 17, no. 2 (2017): 195-202, http:// dx.doi.org/10.20884/1.jdh.2017.17.2.886

Hendrako, Edo. "Hak Waris Anak Perempuan Terhadap Harta Peninggalan (Studi Kasus Putusan MA RI No. 4766/Pdt/1998).” Lex Privatum 3, no. 1 (2015): 84-98.

Polavarapu, Aparna. "Procuring Meaningful Land Rights for the Women of Rwanda." Yale Human Rights and Development Journal 14, no.1 (2014):105-154.

Ramteke, Prerna S., "Knitting the Future Story of Indian Women: Preventing Violence, Fostering Development, and Accelerating Empowerment”, Udayana Journal of Law and Culture 1, no.2 (2017): 98-120. doi:10.24843/UJLC.2017.v01.i02.p02.

Ratmini, Ni Ketut Sri. "Hak Warisan dan Hubungannya Dengan Daha Tua Menurut Hukum Adat Bali." Jurnal Magister Hukum Udayana 4, no. 2 (2015): 391 - 406. https://doi.org/10.24843/JMHU.2015.v04.i02.p19

Setyawati, Ni Kadek. "Kedudukan Perempuan Hindu Menurut Hukum Waris Adat Bali dalam Perspektif Kesetaraan Gender.", Jurnal Penelitian Agama Hindu 1, no. 2 (2017): 618-625.

Westendorp, Ingrid. "Personal Status Law and Women's Right to Equality in Law and in Practice: The Case of Land Rights of Balinese Hindu Women." Journal of Human Rights Practice 7, no.3 (2015): 430-450. https://doi.org/10.1093/jhuman/huv013

\section{Legal Documents}

The 1945 Constitution of the Republic of Indonesia

Indonesian Civil Code

Act of the Republic Indonesia No. 5 Year 1960 concerning Basic Regulations on Agraria

Act of the Republic Indonesia No. 1 Year 1971 concerning Marriage

Act of the Republic of Indonesia No. 39 Year 1999 concerning Human Rights

Provincial Regulation of Bali No. 3 Year 2001 concerning Desa Pakraman 


\section{Case Law}

Decision, Indonesian Supreme Court, No.179K/Sip/1961, dated 23 October 1961.

Decision, Indonesian Supreme Court, No. 100K/Sip/1967 dated14 June 1968.

Decision, Indonesian Supreme Court, No. 4766/Pdt/1998 dated 16 November 1999.

Decision, Indonesian Supreme Court, No. 1048 K/Pdt/2012, dated 26 september 2012.

\section{Website Content}

"Hukum Waris Islam dan Pembagiannya," August 3, 2016, https://dalamislam. com/hukum-islam/hukum-waris-islam

"Tahun 2017 Majelis Utama Desa Pakraman Bali Kukuhkan 5 DP Baru, Salah Satunya di Tabanan," December 8, 2017, https://www.beritabali.com/ read/2017/12/08/201712080017/Tahun-2017-Majelis-Utama-Desa-PakramanBali-Kukuhkan-5-DP-Baru-Salah-Satunya-di-Tabanan.html

\section{Interview}

I Wayan Windia, Interview by Authors. Bali Santhi Secretariat, Denpasar, December 4, 2015 